\title{
Identification of lactoferrin peptides generated by digestion with human gastrointestinal enzymes
}

\author{
C. B. Furlund, ${ }^{* 1}$ E. K. Ulleberg, ${ }^{*}$ T. G. Devold, ${ }^{*}$ R. Flengsrud, ${ }^{*}$ M. Jacobsen, $†$ C. Sekse,‡ H. Holm,§ \\ and G. E. Vegarud* \\ *Department of Chemistry, Biotechnology and Food Science, Norwegian University of Life Sciences, 1432 Ås, Norway \\ †Oestfold Hospital Trust, 1603 Fredrikstad, Norway \\ ¥Norwegian Veterinary Institute, PO Box 750, N-0106 Oslo, Norway \\ $\S$ Department of Nutrition, Institute for Basic Medical Science, University of Oslo, 0316 Oslo, Norway
}

\section{ABSTRACT}

Lactoferrin (LF) is a protein present in milk and other body fluids that plays important biological roles. As part of a diet, LF must survive gastrointestinal conditions or create bioactive fragments to exert its effects. The degradation of LF and formation of bioactive peptides is highly dependent on individual variation in intraluminal composition. The present study was designed to compare the degradation and peptide formation of bovine LF (bLF) following in vitro digestion under different simulated intraluminal conditions. Human gastrointestinal (GI) juices were used in a 2-step model digestion to mimic degradation in the stomach and duodenum. To account for variation in the buffering capacity of different lactoferrin-containing foods, gastric $\mathrm{pH}$ was adjusted either slowly or rapidly to 2.5 or 4.0 . The results were compared with in vivo digestion of bLF performed in 2 volunteers. High concentration of GI juices and fast $\mathrm{pH}$ reduction to 2.5 resulted in complete degradation in the gastric step. More LF resisted gastric digestion when $\mathrm{pH}$ was slowly reduced to 2.5 or 4.0. Several peptides were identified; however, few matched with previously reported peptides from studies using nonhuman enzymes. Surprisingly, no bovine lactoferricin, $f(17-41)$, was identified during in vitro or in vivo digestion under the intraluminal conditions used. The diversity of enzymes in human GI juices seems to affect the hydrolysis of bLF, generating different peptide fragments compared with those obtained when using only one or a few proteases of animal origin. Multiple sequence analysis of the identified peptides indicated a motif consisting of proline and neighboring hydrophobic residues that could restrict proteolytic process-

Received July 16, 2012.

Accepted September 23, 2012.

${ }^{1}$ Corresponding author: camilla.furlund@umb.no or camilla. furlund@hotmail.com ing. Further structure analysis showed that almost all proteolytic cutting sites were located on the surface and mainly on the nonglycosylated half of lactoferrin. Digestion of bLF by human enzymes may generate different peptides from those found when lactoferrin is digested by nonhuman enzymes. The degradation of LF in the GI tract should be taken into consideration when health effects are proposed, because LF has now been approved by the European Food Safety Authority as a dietary supplement in food products.

Key words: human gastrointestinal enzyme, model digestion, lactoferrin, lactoferricin

\section{INTRODUCTION}

Lactoferrin $(\mathbf{L F})$ is an important iron-binding protein in many body fluids, including milk, where it is found in various concentrations among species. Human milk has a higher concentration of LF (1-2 g/L) compared with bovine milk (0.1-0.2 g/L) (Sánchez et al., 1992; Levay and Viljoen, 1995; Hamosh, 1998). However, the use and consumption of bovine milk and dairy products are generally very high in most countries. Recently, the European Food Safety Authority (EFSA) accepted and approved bovine lactoferrin (bLF) as a novel food ingredient (EFSA Panel on Dietetic Products Nutrition and Allergies, 2012). Bovine lactoferrin may therefore soon be added as an ingredient in an increasing number of food products. Many infant formulas enriched with bLF are already available on the market. Orally administered LF in adults exerts several therapeutic effects in vivo, among them improvement of immune and antioxidative status (Mulder et al., 2008).

The antimicrobial properties of LF have been extensively studied, and LF displays antibacterial, antifungal, and antiprotozoal effects as well as effects against viruses (Orsi, 2004). Some LF fragments identified after degradation with commercial enzymes have been reported to have higher bactericidal activity than the mother protein (Hamosh, 1998). In particular, the peptide fragment lactoferricin [LFcin; $\mathrm{f}(17-41)]$, released 
from bLF with bovine and porcine pepsin, has demonstrated strong antimicrobial potential (Bellamy et al., 1992) and antitumor activity (Freiburghaus et al., 2009). Another antimicrobial peptide detected in the N1-domain of LF is lactoferrampin [LFampin; f(268284)], with residues adjacent to the LFcin sequence in the 3-dimensional structure of the molecule (van der Kraan et al., 2004).

It is largely unknown whether LF maintains its integrity and to what degree and at what time it is hydrolyzed into peptides in the gastrointestinal (GI) tract. In addition, whether bioactive peptides such as LFcin are actually formed in the GI tract and would be stable enough to exert the proposed effect is not clear; the few in vivo studies are inconclusive (Chabance et al., 1998; Kuwata et al., 1998a,b, 2001). However, factors such as gastric $\mathrm{pH}$, age of the consumer, and enzyme:substrate ratios seem to be important (Kalantzi et al., 2006). Lactoferrin is only partly digested in neonates and may be absorbed in intact form from the gut of infants (Sánchez et al., 1992; Levay and Viljoen, 1995; Chatterton et al., 2004). Troost et al. (2001) showed that a major proportion (60-80\%) of bLF administered in a high dose $(15 \mathrm{mg} / \mathrm{mL})$ survived passage through the stomach in adults, and that the transit time in the duodenum was 20 to 30 min after instillation. However, in a subsequent study in women with ileostomies, orally ingested human LF was totally degraded in the upper GI tract (Troost et al., 2002).

A challenge in all in vitro model digestions is the simulation of physiological parameters such as variation in enzyme, acid, and bile salt secretions; substrate availability; and transit time in the stomach and duodenum (Ekmekcioglu, 2002; Kalantzi et al., 2006). To date, most peptides have been obtained by in vitro studies using commercial proteases. Human gastrointestinal juices comprise a complex mixture of enzymes present in multiple isoforms, enzyme inhibitors, and bile salts that are important for the digestion process (Scheele et al., 1981; Dunn, 2002; Ekmekcioglu, 2002). Commercial digestive enzymes are purified in most cases from different animal species. In general, enzymes taken from the species to be studied might differ from commercial enzymes of other species concerning specificity, functional enzymatic parameters, and stability. In most in vitro digestion protocols reported, $\mathrm{pH}$ during simulated gastric digestion has been rapidly decreased to 2 or 2.5. Gastric $\mathrm{pH}$ has been shown to decrease gradually after ingestion of a bLF-containing test drink, illustrating the high buffering capacity of LF (Troost et al., 2001). Gastric $\mathrm{pH}$ will have an important effect on the activity of the pepsins as well as on the conformation of the substrate. This subsequently influences the release of peptides during the gastric phase, with regard to specific cleavage points, sequences, and quantity, and it will also affect the subsequent duodenal digestion (Eriksen et al., 2010).

In this study, we aimed to apply an in vitro digestion model using human gastrointestinal enzymes to study the difference in peptide generation of bLF caused by individual variations in gastric $\mathrm{pH}$ and in the amounts of gastric and duodenal juice. A limited in vivo experiment was applied to illustrate variations during in vivo bLF digestion.

\section{MATERIALS AND METHODS}

\section{Lactoferrin}

Bovine LF (95\% purity) was supplied by DMV International (Veghel, the Netherlands) and stored at $-20^{\circ} \mathrm{C}$. Two commercial bLF fragments (lactoferricin, bLFcin) were used: bLFcin $\mathrm{f}(26-36)$ supplied by Sigma (St. Louis, MO) and bLFcin $\mathrm{f}(17-41)$ by GenScript (Piscataway, NJ), with molecular weights of $1,554.87$ and 3,123.9, respectively. Both samples were $>95 \%$ pure and stored at $-20^{\circ} \mathrm{C}$. The bLFcin from GenScript contained a Cys19-Cys36 bridge.

\section{Description of Human Gastric and Duodenal Juices}

Human gastric (HGJ) and duodenal (HDJ) juices were collected from 18 healthy volunteers with no previous history of health impairments according to Ulleberg et al. (2011). In brief, a three-lumen silicone tube developed especially for this purpose by Maxter Catheters (Marseille, France) enabled simultaneous instillation of a stimulation solution and aspiration of gastric and duodenal juices. Aspirates from the stomach and duodenum were collected on ice, with periodic $\mathrm{pH}$ measurements, to control reflux and possible mixing of duodenal and gastric juices. After centrifugation to remove mucus and cell debris $(4,500 \times g$ for $10 \mathrm{~min}$ at $4^{\circ} \mathrm{C}$ ), aliquots were frozen at $-20^{\circ} \mathrm{C}$ and stored at $-80^{\circ} \mathrm{C}$. Pooled samples of HGJ and HDJ from the 18 donors were used in the in vitro digestion experiments described herein.

The aspiration of human contents was approved by the Norwegian Ethics Committee, and all volunteers signed an agreement before participating in the study. Human gastric juice was analyzed for pepsin activity at $\mathrm{pH} 3.0$ with hemoglobin (H2625, Sigma) as substrate within 2 mo after aspiration, and HDJ was analyzed for total proteolytic activity at $\mathrm{pH} 8.0$ with casein (Hammarstein casein, Merck Co., Darmstadt, Germany) as substrate (Ulleberg et al., 2011). 


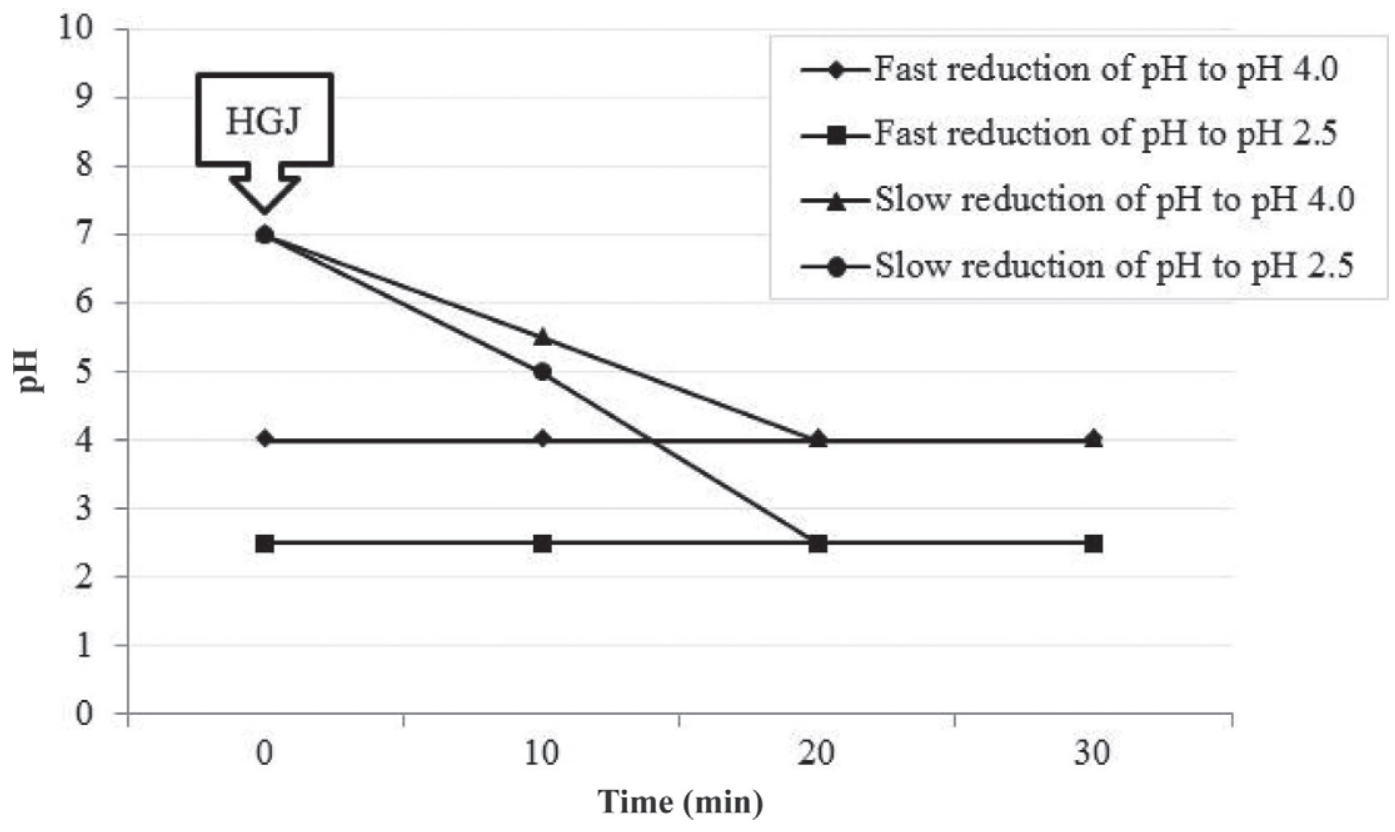

Figure 1. Adjustment of $\mathrm{pH}$ during the course of bovine lactoferrin digestion by human gastric juice (HGJ).

\section{In Vitro Model Digestions}

A 2-step in vitro digestion model with batches of HGJ and HDJ was used to simulate digestion in the stomach and the upper part of the small intestine (Almaas et al., 2006; Eriksen et al., 2010). Initially, bLF was dissolved in distilled water at $\mathrm{pH} 5.0$ to a concentration of $10 \mathrm{mg} / \mathrm{mL}$ (wt/vol). In both digestion steps, continuous magnetic stirring mixed the bLF with the gastric and duodenal juices. In the gastric phase, the samples were acidified by the addition of $1 \mathrm{M} \mathrm{HCl}$ to either $\mathrm{pH} 2.5$ or 4.0. To simulate buffering and nonbuffering conditions, 2 methods to reach the gastric end-pH were used: (1) fast reduction in gastric $\mathrm{pH}$, where $\mathrm{pH}$ was adjusted before the addition of gastric juice, or (2) slow reduction in gastric $\mathrm{pH}$, where the $\mathrm{pH}$ of the bLF solution was first adjusted to 7.0 and then, after addition of HGJ, reduced gradually at 10-min intervals (Figure 1). The time intervals used for the slow reduction in gastric $\mathrm{pH}$ were selected based on in vivo results obtained by Troost et al. (2001). To illustrate variation in the human secretion of digestive juices, HGJ and HDJ were added at 2 concentrations. To the $10 \mathrm{mg} / \mathrm{mL}$ bLF solution, 5 or $20 \mathrm{U}$ of pepsin in HGJ was added per gram of bLF (19 or $77 \mu \mathrm{L}$ to $10 \mathrm{~mL}$ of bLF solution). The subsequent duodenal digestion was performed at $\mathrm{pH} 7.0$ for another 30 min using HDJ at an activity of 15.6 or $62.4 \mathrm{U} / \mathrm{g}$ of bLF (96 or $384 \mu \mathrm{L}$ to $10 \mathrm{~mL}$ of bLF solution). Aliquots were removed after each of the 2 digestion steps, placed on ice, and frozen. All digestions were run in duplicate.
Two commercial bovine bLFcin of different sequences, $f(26-36)$ and $f(17-41)$, were digested according to the slow reduction in gastric $\mathrm{pH}$ to 2.5 as described above. These peptides were chosen based on their potential antimicrobial activity. Then, $0.1 \mathrm{mg} / \mathrm{mL}$ bLFcin was dissolved in water, HGJ (20 U/g protein) was added, $\mathrm{pH}$ gradually reduced to $\mathrm{pH} 2.5$, and digestion continued for a total of $30 \mathrm{~min}$. After $\mathrm{pH}$ adjustment to 7.0, HDJ (62.4 U/g of protein) was added and the incubation continued. Samples were withdrawn from the gastric step at $30 \mathrm{~min}$ and from the duodenal step after 15, 60, and $120 \mathrm{~min}$. Samples were frozen before analysis, and digestions were run in duplicate.

\section{In Vivo Digestion of bLF}

After an overnight fast, 2 healthy volunteers were intubated with three-lumen tubes, as described by Ulleberg et al. (2011). A small volume of digestive juice was withdrawn from the stomach and duodenum before administration of $200 \mathrm{~mL}$ of a $10 \mathrm{mg} / \mathrm{mL}$ solution of bLF to the stomach. Samples were then withdrawn after 10 and $30 \mathrm{~min}$ from the stomach and after 5, 10, 20, 30, 40 , and $50 \mathrm{~min}$ from the duodenum. The aspirates were collected on ice and centrifuged to remove mucus and cell debris $\left(4,500 \times g\right.$ for $10 \mathrm{~min}$ at $\left.4^{\circ} \mathrm{C}\right)$, before freezing the supernatant at $-20^{\circ} \mathrm{C}$ and storing at $-80^{\circ} \mathrm{C}$. Degradation of bLF was visualized by SDS-PAGE and the peptides were identified by liquid chromatographytandem MS (LC-MS/MS). 


\section{Protein Degradation Profiles}

Protein degradation profiles of intact and digested bLF were studied by SDS-PAGE using 15 or $12.5 \%$ acrylamide gels (Bio-Rad Mini-Protean 3 cell system, Bio-Rad Laboratories Ltd., Hemel Hempstead, UK; Laemmli, 1970). The low-molecular-weight (LMW) marker $(97,66,45,30,20.1$, and $14.4 \mathrm{kDa})$ was supplied by GE Healthcare (Little Chalfont, UK). Samples were mixed 1:2 with $2 \times$ SDS sample buffer $[0.125 M$ Tris-Cl, $4 \%$ SDS, $2 \%$ glycerol (vol/vol), $2 \%$ 2-mercaptoethanol (vol/vol), and $0.03 \mathrm{~m} M$ bromophenol blue (vol/vol)] and heated at $95^{\circ} \mathrm{C}$ for 5 min before application to the gel. Electrophoresis was run at $50 \mathrm{~V}$ for $20 \mathrm{~min}$, and then at $150 \mathrm{~V}$ for $50 \mathrm{~min}$ or at $200 \mathrm{~V}$ for $50 \mathrm{~min}$ (PowerPac basic, Bio-Rad). Proteins were visualized by staining with Coomassie Brilliant Blue R-250.

\section{Degree of Hydrolysis}

The spectrophotometric o-phthaldialdehyde (OPA) assay by Church et al. (1983) with some modifications was used to measure protein hydrolysis in the HGJ and HDJ digested samples with a high concentration of enzymes. In brief, 100 to $200 \mu \mathrm{L}$ of sample [diluted 1:10 in $100 \mathrm{~m} M$ sodium tetraborate and $2 \%$ (wt/wt) SDS to stop proteolysis] was added to $1.0 \mathrm{~mL}$ of OPA reagent [100 $\mathrm{m} M$ sodium tetraborate, $2 \%$ (wt/wt) SDS, $6 \mathrm{mM}$ OPA (28.5 mM $\beta$-mercaptoethanol)]. After $2 \mathrm{~min}$ of incubation at ambient temperature, absorbance was read at $340 \mathrm{~nm}$ (UV-106A, Shimadzu, Duisberg, Germany); unhydrolyzed bLF was used as the negative control. Protein concentrations in unhydrolyzed and hydrolyzed samples were assayed using the absorbance at $280 \mathrm{~nm}$ against a bLF standard curve. Protein hydrolysis is expressed as degree of hydrolysis (DH), defined as the percentage peptide bonds hydrolyzed by the gastric and duodenal enzymes. All samples were run in triplicate.

\section{Identification of Proteins by In-Gel Digestion}

Samples collected after the in vivo experiments were separated on a 12.5\% SDS-PAGE gel. A selection of the protein bands were excised out of the gel and subjected to in-gel reduction, alkylation, and tryptic digestion (Shevchenko et al., 1996), as reported in Eriksen et al. (2010).

\section{Preparation of Low-Molecular-Weight LF Peptides}

Low-molecular-weight $(<10 \mathrm{kDa})$ peptides in the $\mathrm{LF}$ digests were obtained by filter centrifugation using a 10-kDa Millipore Amicon Ultra-15 centrifugal cut-off filters (Amicon, Millipore, Bedford, MA). The LMW fractions were dissolved in $0.1 \%$ (vol/vol) formic acid before being desalted and concentrated using self-made C18 columns. The columns consisted of $\mathrm{C} 18$ column material (3M Empore C18 extraction disks, 3M Bioanalytical Technologies, St Paul, MN) inserted into Eppendorf GELoader micropipette tips (Hamburg, Germany). The peptides were eluted using $3 \mu \mathrm{L}$ of $70 \%$ acetonitrile and $0.1 \%$ formic acid ( $\mathrm{vol} / \mathrm{vol})$.

\section{MS Identification of Peptides}

Commercial bLFcin and LMW peptide fractions were diluted in $10 \mu \mathrm{L}$ of $1 \%$ (vol/vol) formic acid and loaded onto a nanoAcquity Ultra Performance LC system (Waters Corp., Milford, MA), equipped with a Symmetry C18 $(180 \mu \mathrm{m} \times 22 \mathrm{~mm}$; Waters Corp.) column in front of a $3-\mu \mathrm{m}$ Atlantis C18 analytical column $(100 \mu \mathrm{m} \times$ $100 \mathrm{~mm}$; Waters Corp.), as described in Eriksen et al. (2010).

The identified peptides resulting from the bLF digestion were chosen to include all detected residues with minimal overlap and studied by using Clustal 2.0.12 and ClustalW2 multiple sequence alignment (MSA; http://www.ebi.ac.uk/Tools/clustalw2/). The alignment was analyzed using the multiple sequence editor Jalview (Waterhouse et al., 2009). Default settings were used for both programs. The localization of the proteolytic cutting sites was also studied using the 3-dimensional structure of bovine lactoferrin (1BLF, Protein Data Bank, http://www.rcsb.org; code: http://www. ebi.ac.uk/pdbsum/1blf) in Jmol Protein Explorer 0.5 (http://www.umass.edu/molvis/martz/). The spacefill presentation of the molecular structure was used to distinguish between surface and internal residues.

\section{RESULTS}

\section{Effect of Gastric pH}

Gastric digestion of bLF $(10 \mathrm{mg} / \mathrm{mL})$ at $\mathrm{pH} 2.5$ and 4.0 resulted in different protein degradation profiles (Figure 2). In general, a slow reduction in gastric $\mathrm{pH}$ resulted in more intact bLF than did fast $\mathrm{pH}$ reduction. The greatest gastric degradation of bLF was observed after fast reduction to gastric $\mathrm{pH} 2.5$, when no intact bLF remained after $30 \mathrm{~min}$ of digestion (Figure 2, lane 7). Further degradation of the peptides (molecular weight $<45 \mathrm{kDa}$ ) occurred when HDJ was added (Figure 2, lane 8 ). This was also confirmed by the OPA assay, which showed a greater degree of hydrolysis for fast $\mathrm{pH}$ reduction to $\mathrm{pH} 2.5(\mathrm{DH} \sim 10.7 \%$ ) compared with $\mathrm{pH} 4.0$ ( $\mathrm{DH} \sim 6.8 \%$ ) after duodenal digestion. In addition, when digestion was performed at gastric $\mathrm{pH}$ 4 , the fast $\mathrm{pH}$ reduction resulted in greater degrada- 


\section{kDa}

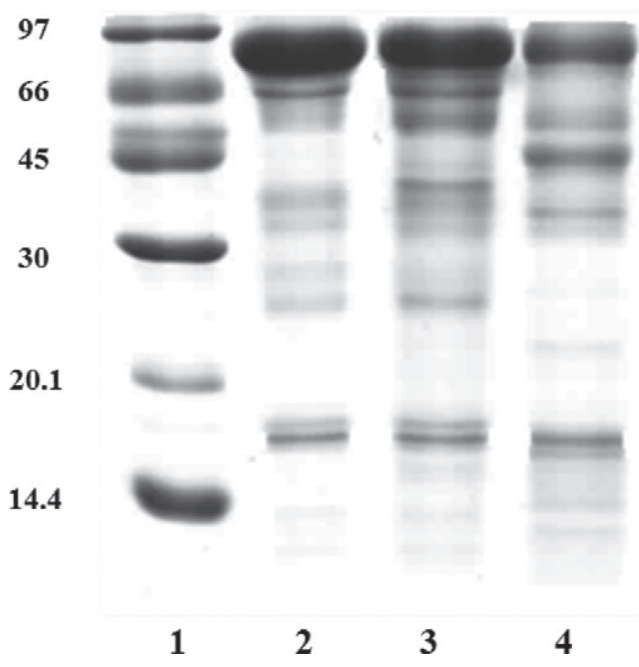

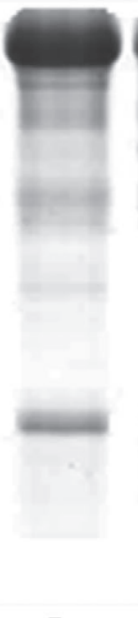

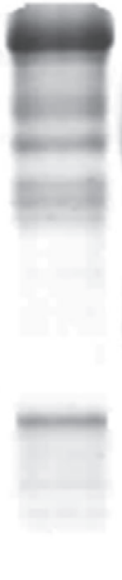

5

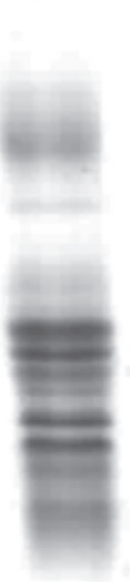

7

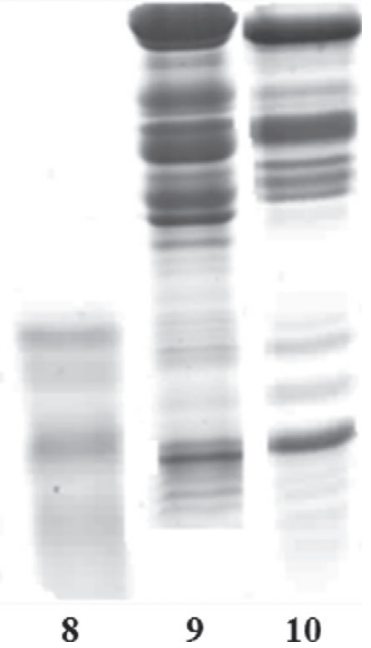

Figure 2. Protein profiles of native bovine lactoferrin (bLF; $10 \mathrm{mg} / \mathrm{mL}$ ) digested with human gastric juice (HGJ, 20 U/g) and human duodenal juice (HDJ, $62.4 \mathrm{U} / \mathrm{g}$ ) by slow and fast acid reduction to $\mathrm{pH} 2.5$ and 4.0. Lane $1=$ molecular weight marker; lane $2=$ undigested bLF; lane 3 = slow reduction to $\mathrm{pH} 2.5$, HGJ, $30 \mathrm{~min}$; lane $4=$ slow reduction to $\mathrm{pH} 2.5$, HGJ + HDJ, 30 min; lane $5=$ slow reduction to $\mathrm{pH} 4.0$, $30 \mathrm{~min}, \mathrm{HGJ}$; lane $6=$ slow reduction to $\mathrm{pH} 4.0$, HGJ + HDJ, $30 \mathrm{~min}$; lane 7 = fast reduction to $\mathrm{pH} 2.5$, HGJ, 30 min; lane $8=$ fast reduction to $\mathrm{pH} 2.5$, HGJ + HDJ, $30 \mathrm{~min}$; lane $9=$ fast reduction to $\mathrm{pH} 4.0$, HGJ, $30 \mathrm{~min}$; lane 10 = fast reduction to $\mathrm{pH} 4.0$, HGJ + HDJ, 30 min.

tion, as less intact bLF remained and more peptide bands seemed to appear at 66 to $30 \mathrm{kDa}$ (Figure 2, lanes 5 and 9). Intact bLF was still present after HDJ digestion, with one exception ( $\mathrm{pH} 2.5$ fast reduction).

Peptide identification by LC-MS/MS revealed that duodenal digestion gave rise to more peptides of lower molecular weight compared with only the gastric digestion (Figure 3). One exception was observed for the
bLF digested at gastric $\mathrm{pH} 4$ (fast reduction), where more peptides were identified after the gastric step compared with the duodenal step.

\section{Effect of Different Amounts of Digestive Juices}

To simulate variation in gastrointestinal enzyme secretion, this study was conducted using 2 enzyme

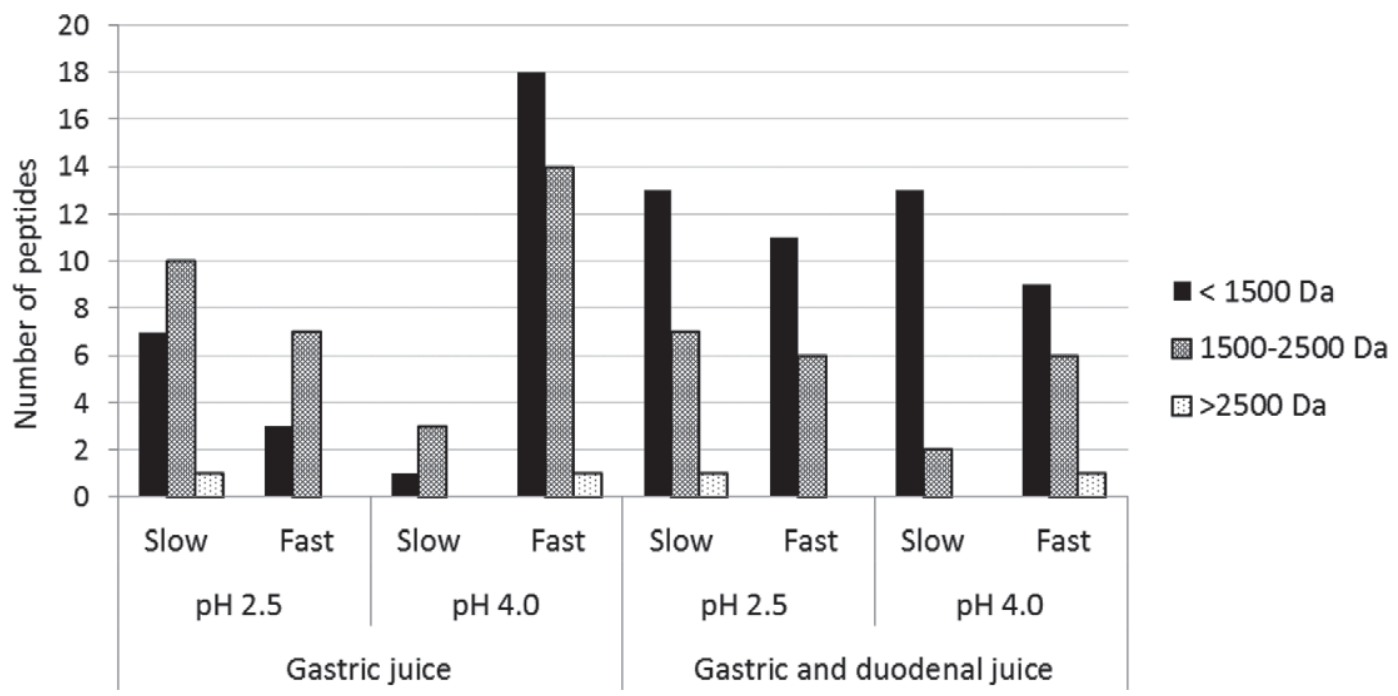

Figure 3. Number of peptides $(<1,500 \mathrm{Da}, 1,500-2,500 \mathrm{Da}$, and $>2,500 \mathrm{Da})$ identified in samples of bovine lactoferrin digested using either slow or fast adjustment of the gastric $\mathrm{pH}$ to reach 2.5 or 4.0. Slow denotes a gradual $\mathrm{pH}$ decrease after addition of gastric juice and fast represents a constant $\mathrm{pH}$ throughout the gastric step. 
concentrations: one representing the mean values of the HGJ batch (5 U/g) and the HDJ batch (15.6 U/g) and the other being 4 times higher. It was evident that the degradation of bLF was highly dependent on the amount of digestive juices added (data not shown). When the higher concentrations of HGJ $(20 \mathrm{U} / \mathrm{g})$ and HDJ $(62.5$ $\mathrm{U} / \mathrm{g}$ ) were used, a large part of undigested bLF was still present; however, more fragments (molecular weights $35-65 \mathrm{kDa}$ and $<20 \mathrm{kDa}$ ) were generated.

\section{Identification of Peptides After Digestion of $b L F$ and Lfcin}

Several peptides were identified from bLF digested with HGJ and HDJ at pH 2.5 and 4.0 with the higher concentration of enzymes (Figure 4). Approximately $70 \%$ of the detected peptides originated from the Nterminal region of the bLF molecule, and very few peptides were detected in the C-terminal region. After gastric digestion, longer peptides were produced, and they were degraded into shorter peptides with further HDJ digestion. Several peptides originated from the same part of the protein and varied in length by only a few amino acids, including $\mathrm{f}(100-109)$ and $\mathrm{f}(100-111), \mathrm{f}(122-134)$ and $\mathrm{f}(122-139)$, and $\mathrm{f}(125-228)$ and $\mathrm{f}(216-229)$. All identified peptides are included in Supplemental Table S1 (available at http://www. journalofdairyscience.org/).

In this study, one peptide, f(271-288), corresponding to a large part of the bovine LFampin sequence, was identified after gastric digestion at slow reduction to $\mathrm{pH}$ 2.5. However, no peptides corresponding to bLFcin were detected after in vitro digestion of bLF under the various conditions. To ensure that bLFcin was detectable during LC-MS/MS analysis, 2 undigested commercial bLFcin, $f(26-36)$ and $f(17-41)$, were analyzed together with the generated bLF peptides. A single peptide fragment with molecular weight of $1,543.8670$ (RRWQWRMKKLG) was identified as bLFcin f(26-36), whereas no peptide identified as bLFcin $\mathrm{f}(17-41)$ was observed. However, a peptide with the monoisotopic mass of 3,121.68 was detected for bLFcin f(17-41), corresponding to the molecular mass of bLFcin. This peptide contains a disulfide bridge between residues 19 and 36, which generates a complex peptide spectrum that cannot be detected in the Mascot program used. Disulfide-containing peptides in this area were therefore manually detected and calculated as masses from the spectra. To observe if any of the commercial bLFcin sequences were further digested by HGJ at $\mathrm{pH}$ 2.5 , peptides generated after bLFcin digestion were analyzed as well. No peptide fragments were detected from bLFcin $\mathrm{f}(26-36)$, whereas for bLFcin $\mathrm{f}(17-41)$,
3 smaller peptide sequences were observed: $\mathrm{f}(23-30)$ (QWRMKKLG), f(20-30) (RWQWRMKKLG), and $\mathrm{f}(20-31)$ (RRWQWRMKKLGA).

\section{In Vivo Digestion of bLF}

To compare the in vitro model digestion of bLF with in vivo digestion, we performed an ingestion study with 2 volunteers. Samples were withdrawn during the 50min experiment from the gastric and duodenal compartments. Figures $5 \mathrm{a}$ and $\mathrm{b}$ show the resulting protein profiles for volunteers 1 and 2, respectively, and Table 1 gives an overview of the bLF peptides that were detected throughout the in vivo digestion. The protein profiles for the gastric sample collected 10 min after administration of bLF were similar for the 2 volunteers. Twenty-one peptides were identified in the gastric samples from volunteer 1 and 15 peptides from volunteer 2. Of these peptides, 11 were common to both samples. In the gastric sample from volunteer 1 aspirated after 30 min, no intact bLF or high-molecular-weight protein bands were visible (Figure 5a, lane 5), and only 4 peptides were identified (Table 1 ). No gastric sample was withdrawn from volunteer 2 after $30 \mathrm{~min}$.

After $30 \mathrm{~min}$, the protein profiles in the duodenal samples from both volunteers were similar to that observed for HDJ before administration of bLF (HDJ at 0 min). In addition, no bLF peptides were detected after $30 \mathrm{~min}$. The duodenal sample withdrawn from the 2 volunteers after $30 \mathrm{~min}$ had a $\mathrm{pH}$ ranging from 6.5 to 7.5 and from 2.8 to 4.0 for volunteers 1 and 2, respectively. In Figure 5b, it can be seen that none of the protein bands that were visible in the pure HDJ sample were present during the first $20 \mathrm{~min}$ of the experiment. In addition, for the first $20 \mathrm{~min}$, only 2 peptides were identified in the duodenal samples from volunteer 1 compared with a total of 27 peptides for volunteer 2 . Some peptides seemed stable during digestion for volunteer 2, as they were identified in gastric samples after 10 min as well as in all 3 duodenal samples collected 5, 10, and 20 min after administration of bLF (Table 1). In-gel digestion and MS analysis of the gel-bands in the duodenal samples from volunteer 1 showed that several fragments of digested bLF were generated during the first 20 min of digestion (data not shown).

No sequence comparable to bLFcin $\mathrm{f}(17-41)$ was identified in either of the volunteers; however, 2 large parts of the bLFampin sequence $\mathrm{f}(268-284)$, namely $f(271-285)$ and $f(271-287)$, were identified in the duodenal sample from volunteer 2 collected after 20 min. After $10 \mathrm{~min}$, a peptide containing part of the bLFampin sequence was also identified in the gastric sample from volunteer $1[\mathrm{f}(258-279)]$. 
$2.5 \mathrm{G} \quad 1$

$4.0 \mathrm{G} \quad 1$

$2.5 \mathrm{D}$

$4.0 \mathrm{D}$

$2.5 \mathrm{G} \quad 91$

$4.0 \mathrm{G}$

$2.5 \mathrm{D} \quad 91$

4.0 D 91

2.5 G 181

4.0 G 181

$2.5 \mathrm{D} 181$

4. 0 D 181

4.0 G 271

$2.5 \mathrm{D} 271$

4.0 D 271

2.5 G 361

$4.0 \mathrm{G} 361$ WSQQSGONVT CATASTTDDC

2.5 D 361 WSOOSGONVT CATASTTDDC

4.0 D 361 WSQQSGQNVT CATASTTDDC

4.0 G 451

$\begin{array}{lll}2.5 & \text { D } & 451 \\ 4.0 & \text { D } & 451\end{array}$

LKDKKSCHTA VDRTAGWNIP MGLIVNQTGS CAE 4.0 G 541 AFVKNDTVWE NTNGESTADW AKNLNREDFR LLCLDGTRKP VTEAQSCHLA VAPNHAVVSR SDRAAHVKQV LLHQQALFGK NGKNCPDKFC 2.5 D 541 AFVKNDTVWE NTNGESTADW AKNLNREDFR LLCLDGTRKP VTEAQSCHLA VAPNHAVVSR SDRAAHVKQV LLHOQALFGK NGKNCPDKFC 4.0 D 541 AFVKNDTVWE NTNGESTADW AKNLNREDFR LLCLDGTRKP VTEAQSCHLA VAPNHAVVSR SDRAAHVKQV LLHQQALFGK NGKNCPDKFC

2.5 G 631 LEKSETKNLL FNDNTECLAK LGGRPTYEEY LGTEYVTAIA NLKKCSTSPL LEACAFLTR

4.0 G 631 LFKSETKNLL FNDNTECLAK LGGRPTYEEY LGTEYVTAIA NLKKCSTSPL LEACAFLTR

2.5 D 631 LFKSETKNLL FNDNTECLAK LGGRPTYEEY LGTEYVTAIA NLKKCSTSPL LEACAFLTR

4.0 D 631 LFKSETKNLL FNDNTECLAK LGGRPTYEEY LGTEYVTAIA NLKKCSTSPL LEACAFLTR

90

Figure 4. Peptide regions (in bold text) for bovine lactoferrin $(10 \mathrm{mg} / \mathrm{mL}$ ) generated by fast reduction to $\mathrm{pH} 2.5$ and $\mathrm{pH} 4.0$, for samples digested with gastric juice (G) and samples digested with gastric and duodenal juice (D). Disulfide bridges are located between cysteines (C; shaded) 9-45, 19-36, 115-198, 157-173, 170-181, 231-245, 348-380, 358-371, 405-684, 425-647, 457-532, 481-675, 491-505, 502-515, 573-587, and 652-630. 


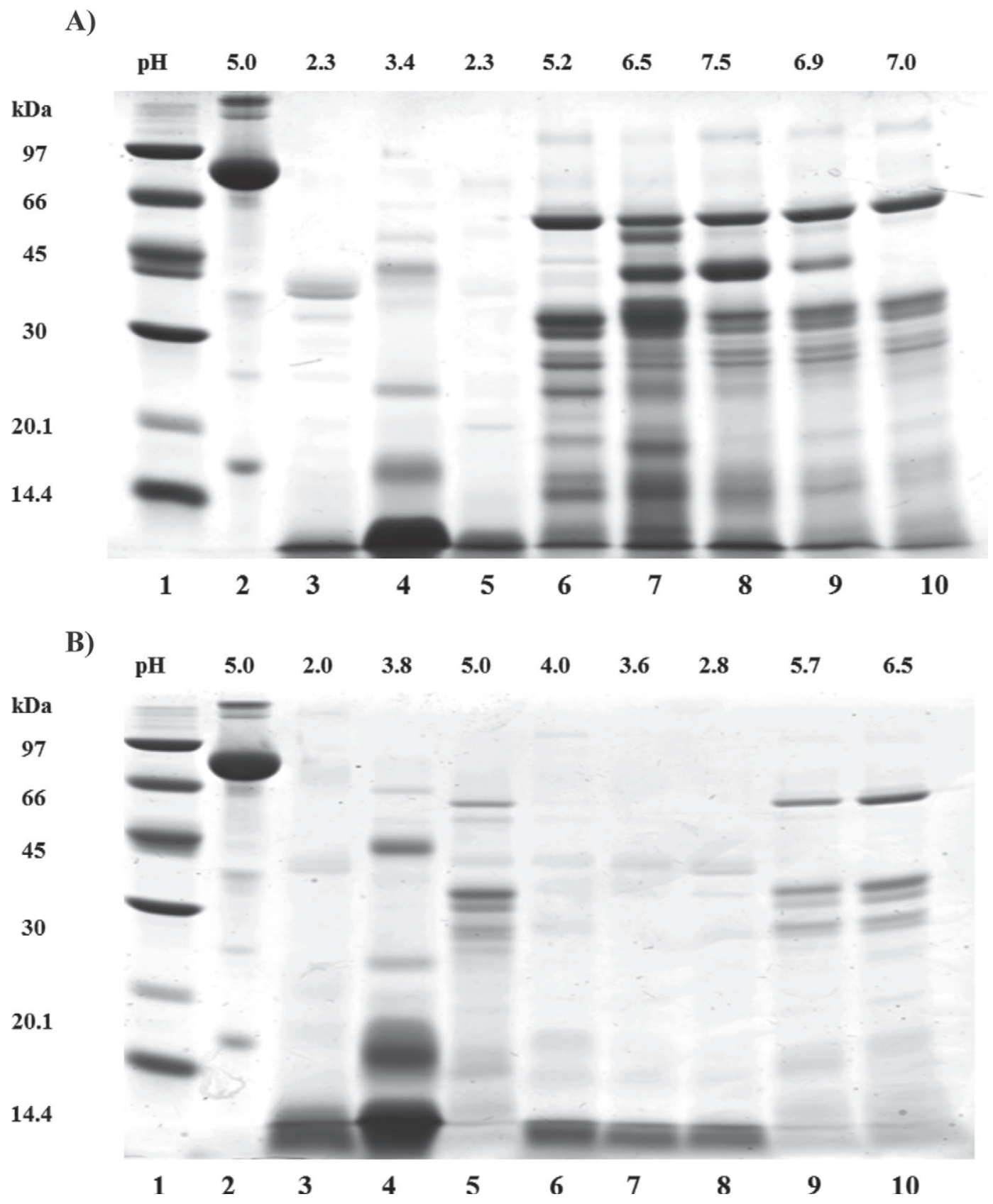

Figure 5. In vivo digestion of bovine lactoferrin (bLF, $200 \mathrm{~mL}$ of $10 \mathrm{mg} / \mathrm{mL}$ ) performed in 2 volunteers (volunteer 1 in panel A; volunteer 2 in panel B). A) Lane $1=$ molecular weight marker; lane $2=$ undigested bLF; lane $3=$ gastric juice before adding bLF; lane $4=$ gastric sample 10 min after adding bLF; lane $5=$ gastric sample $30 \mathrm{~min}$ after adding bLF; lane $6=$ duodenal juice before adding bLF; lanes $7-10=$ duodenal samples 5, 10, 20, and 30 min after adding bLF, respectively. B) Lane $1=$ molecular weight marker; lane $2=$ undigested bLF; lane $3=$ gastric juice before adding bLF; lane $4=$ gastric sample 10 min after adding bLF; lane $5=$ duodenal juice before adding bLF; lanes 6 - $10=$ duodenal samples 5, 10, 20, 30, and 40 min after adding bLF, respectively.

\section{Sequence Alignment and Location of Identified Peptides}

We performed MSA of all the peptides to show any common pattern and cleavage sites of the GI enzymes. The results of the alignment of the peptides obtained from bLF after in vitro and in vivo digestion are presented in Figure 6 (panel A: in vitro $\mathrm{pH} 2.5$; panel B: in vitro $\mathrm{pH} 4.0$, and panel C: in vivo). The peptides submitted to MSA were chosen to have all detected peptides represented and yet minimize any overrepresentation of particular parts of the residues. 
Table 1. Bovine lactoferrin (bLF) peptides identified in samples aspirated from 2 volunteers ${ }^{1}$

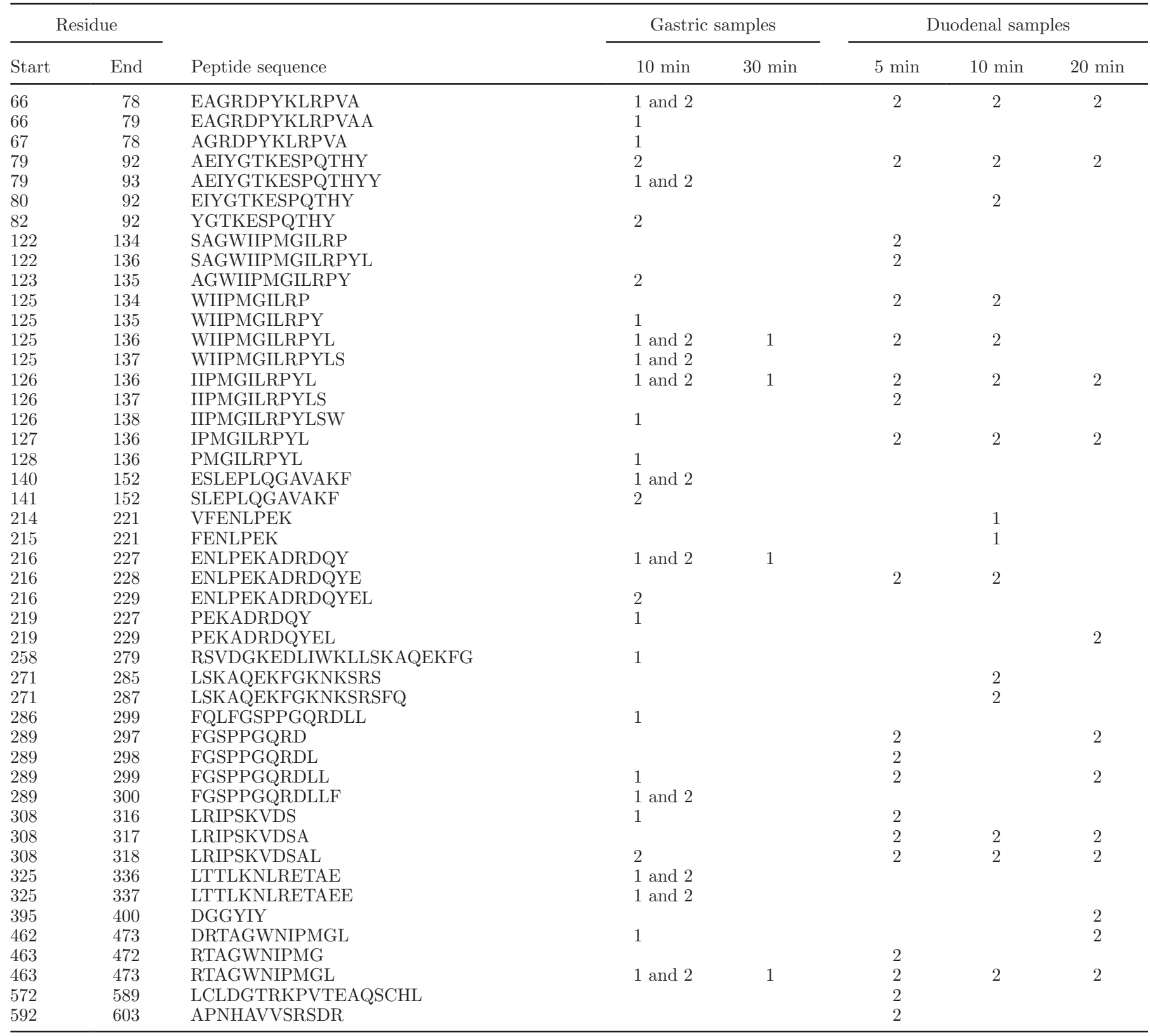

${ }^{1}$ Numbers 1 and 2 indicate in which volunteer each peptide was identified. The samples were collected 10 and 30 min after administration of bLF from the gastric compartment and after 5, 10, 20,30,40, and 50 min from the duodenal compartment. Volunteer 2 did not produce a gastric sample after $30 \mathrm{~min}$; however, gastric juice and bLF seemed to be transferred directly to the duodenum within 5 min. No peptides were identified in the samples collected after $30 \mathrm{~min}$ and later.

The peptide analysis from in vitro digestion at $\mathrm{pH} 2.5$ showed that the presence of proline with neighboring hydrophobic residues, preferably leucines, could be a motif for preferred uncleaved peptide bonds under these conditions. The peptides generated at $\mathrm{pH} 4.0$ (in vitro) showed a somewhat different pattern, in which lysine, alanine, and multiple leucine residues were in the consensus sequence. The peptides generated in vivo show the putative proline-leucine motif. In all 3 align- ments, several leucines, as well as alanine and glycine, were present.

For all peptides identified in the in vitro and in vivo experiments, analysis of the protease cutting sites in the 3-dimensional structure using the structure $1 \mathrm{BLF}$ (Protein Data Bank code) in Jmol Protein Explorer 0.5 showed that these sites, with a few exceptions, were localized on the surface of the lactoferrin molecule (Figure 7). 
A) Q $>15$ is marked (*), alignment score: $\mathbf{5 - 5 0}$

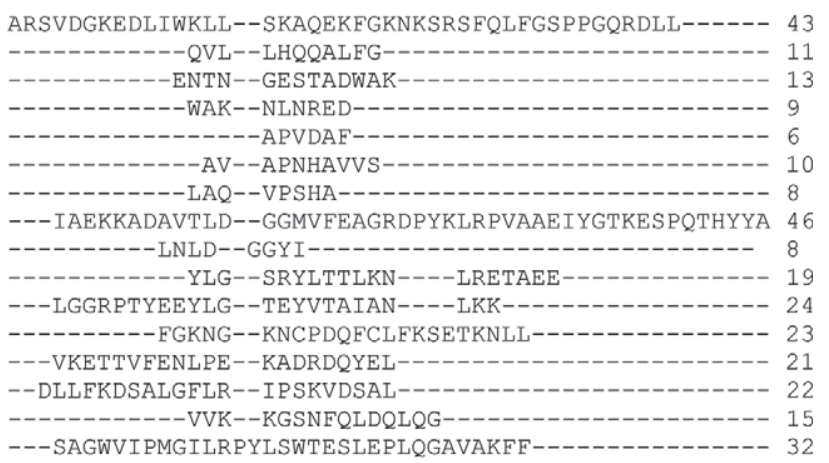

---SAGWVT PMGIIRPYISWTESIRPIQGAVAKFE--------0--

$\begin{array}{llllllllll}\text { AGK } & \text { EG } & \text { LG } & \text { PS } & \text { A L L L } & \text { L } & \text { KL } & \text { E } & G\end{array}$

B) $\mathbf{Q}>\mathbf{2 0}$ is marked (*), alignment score: 5-63

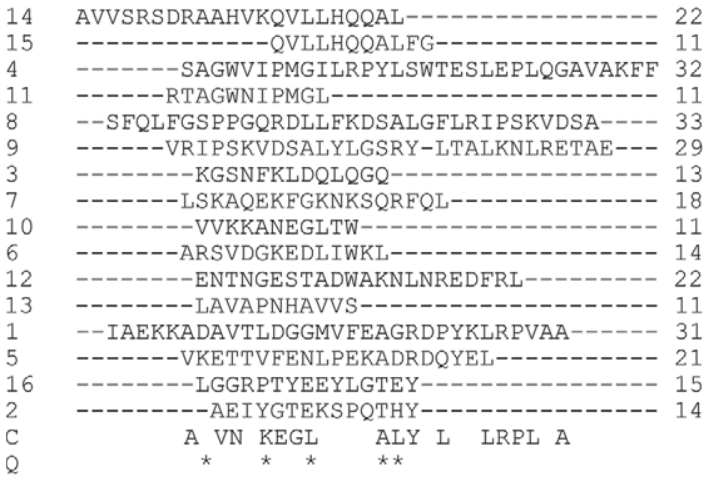

C) $Q>6$ is marked $\left({ }^{*}\right)$, alignment score $0-58$

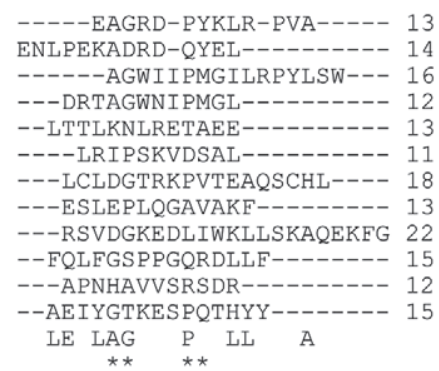

Figure 6. Multiple sequence alignment (MSA) using CLUSTAL 2.0.12 of the peptides generated after in vitro gastro-duodenal digestion of $\mathrm{LF}$ at (A) $\mathrm{pH} 2.5$ and (B) $\mathrm{pH} 4.0$; (C) MSA (ClustalW2) of peptides generated after in vivo digestion. The numbers on the left indicate the numbering of detected peptides with minimal overlap, starting from the N-terminal. The numbers on the right indicate the number of residues. $\mathrm{C}=$ consensus sequence, $\mathrm{Q}=$ quality factor obtained from the JalView program (Waterhouse et al., 2009) in default mode.

\section{DISCUSSION}

This study was designed to examine bLF degradation products released during simulated human gastrointestinal digestion. In an attempt to confirm the in vitro results with in vivo results, 2 volunteers ingested bLF in the same amount as was used in the in vitro experiments.

Most of the in vitro digestion models previously reported have used commercial enzymes of nonhuman origin (Dionysius and Milne, 1997; Hoek et al., 1997; Kimura et al., 2000; Recio and Visser, 2000; Liepke et al., 2002; Chatterton et al., 2004; Elbarbary et al., 2010). Our study was conducted with human gastrointestinal juices, which are natural mixtures of enzymes presented in multiple isoforms, as well as enzyme inhibitors, bile salts, bilirubin, and other minor components that may influence protein degradation (Scheele et al., 1981; Dunn, 2002; Ekmekcioglu, 2002). In contrast, most model digestion assays use commercial enzymes that are purified proteases of animal origin and consist mainly of one enzyme, such as pepsin, trypsin, or

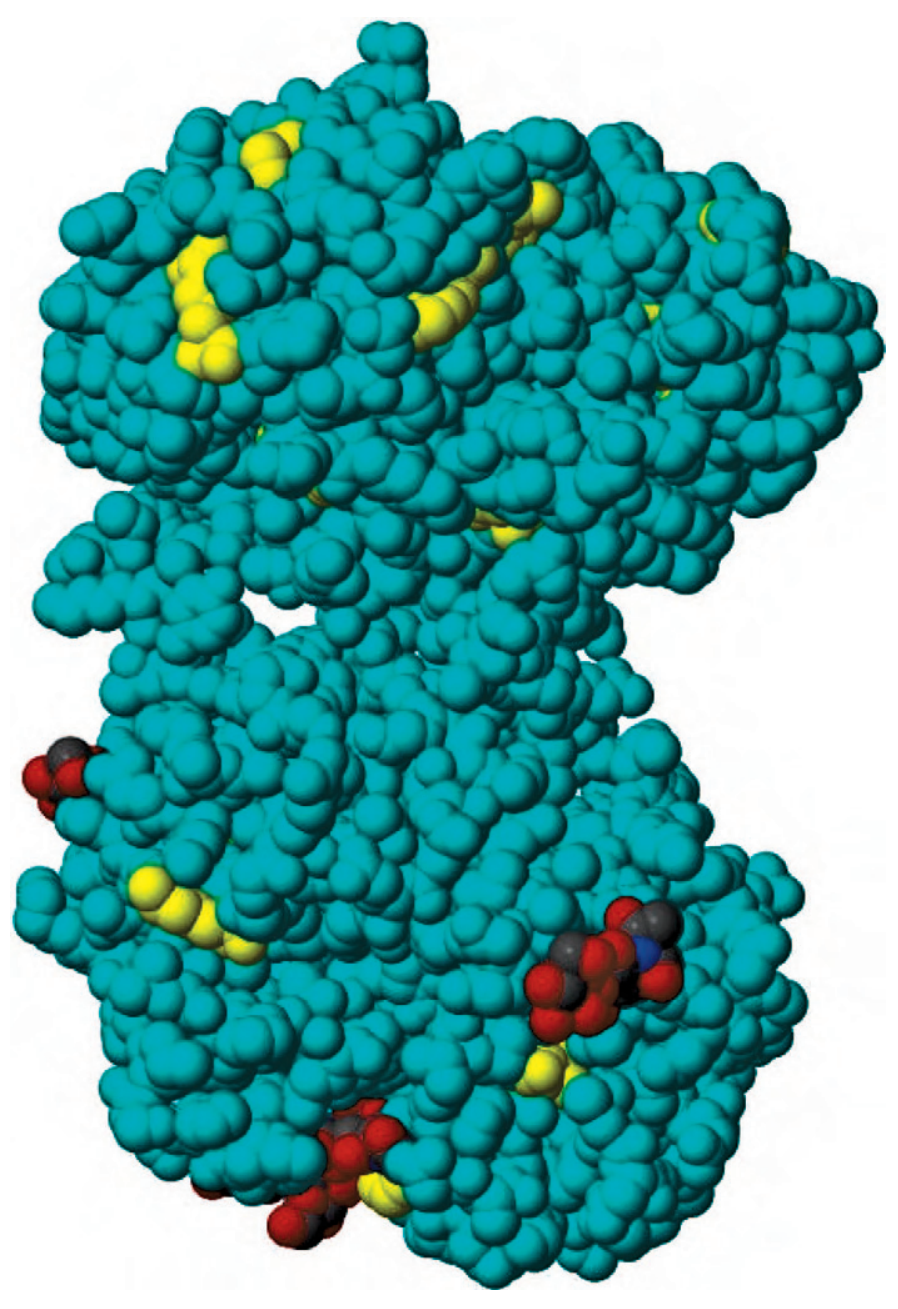

Figure 7. Excerpt of the 3-dimensional structure of bovine lactoferrin (Protein Data Bank, http://www.rcsb.org; code 1BLF) with the $\mathrm{N}$-terminal residues of processed peptide bonds at the N-terminal part of identified peptides. The residues are shown in white (yellow) and the 3 glycosyl residues in the C-terminal part of protein in the darkest gray (red, gray, and blue). Color version available in the online PDF. 
chymotrypsin, or a combination of purified enzymes in different ratios. Reports vary and are contradictory with regard to the resistance of LF to degradation by various commercial enzymes (Brines and Brock, 1983; Tomita et al., 1991; Baldi et al., 2005; Gonzalez-Chavez et al., 2009). The challenge with this approach is to use a representative ratio with contributions from all the different proteases and other gut components (e.g., bile salts) similar to what is found in human GI juices during digestion. In this regard, Macierzanka et al. (2009) demonstrated that phospholipids present in the gastrointestinal tract affect the in vitro digestion of the milk proteins $\beta$-casein and $\beta$-lactoglobulin in emulsions. Such phospholipids are rarely present when performing in vitro digestion using simple commercial enzymes but could be part of GI juices. In humans, individual variation in gastric and duodenal secretions is observed, but pooled samples of gastric or duodenal juices, or combinations thereof, may account for the mean variations between individuals. However, variation in the pooled batches may occur because of individual variation. The enzyme activity and secreted volume of gastric and duodenal juices vary not only between individuals, but also within an individual (Keller and Layer, 2005; Ulleberg et al., 2011). The complete hydrolysis of LF observed in the in vivo digestion experiment may indicate that the enzyme concentration used in the in vitro digestion was too low compared with that of the 2 volunteers in the in vivo study.

To simulate intragastric $\mathrm{pH}$ variation and buffering capacity of bLF-containing food, 2 different gastric $\mathrm{pH}$ values (2.5 and 4.0) were used in this study, in addition to fast and slow reductions of $\mathrm{pH}$. The variation in gastric $\mathrm{pH}$ used in our digestion model reflects the previously reported in vivo results. Fasting gastric $\mathrm{pH}$ values of neonates have been shown to be 6 to 8 , decreasing to approximately 1.5 at 1 mo of age (Fallingborg et al., 1990b; Kaye, 2011), whereas in adults the $\mathrm{pH}$ is in the range of 1.0 to 3.5 (Dressman et al., 1990; Fallingborg et al., 1990a; Ekmekcioglu, 2002). Variations in gastric $\mathrm{pH}$ in the fed state depend greatly on the buffering capacity of the ingested food, often being in the range of $\mathrm{pH} 2$ to 4 (Dressman et al., 1990; Fallingborg et al., 1990b; Ekmekcioglu, 2002). In this study, pH in the samples collected after $10 \mathrm{~min}$ of in vivo gastric digestion of bLF was 3.4 for volunteer 1 and 3.8 for volunteer 2. Troost et al. (2001) previously reported that gastric $\mathrm{pH}$ decreased slowly in adult humans after ingestion of bLF. In addition, Chatterton et al. (2004) illustrated the high buffering capacity of milk by a fast increase in $\mathrm{pH}$ to 6.5 immediately after ingestion of milk in neonates, followed by a slow reduction of gastric $\mathrm{pH}$ to values between 3.5 and 4 within 180 to $210 \mathrm{~min}$. Dressman et al. (1990) also reported a slow reduction of gastric $\mathrm{pH}$ in the stomach after food ingestion in healthy young men and women.

In this study, the greatest in vitro degradation of bLF, leaving no intact protein, was observed when gastric $\mathrm{pH}$ was adjusted to 2.5 before addition of HGJ. In comparison, after a 10-min gastric digestion in vivo, both volunteers seemed to have no intact bLF left, indicating either that all bLF was digested to shorter fragments or that the partially degraded and intact bLF had been transferred to the duodenum. Troost et al. (2001) showed that the transit time was approximately 20 to 30 min and that as much as 60 and $80 \%$ of the apo and holo forms of bLF, respectively, resisted gastric digestion. In a subsequent study (Troost et al., 2002), bLF was totally degraded in the upper GI tract. In accordance with that report, our in vivo study showed neither intact bLF nor fragments of the protein after 30 min in the duodenum for either volunteer. In contrast, a large amount of intact bLF was left when simulating buffering conditions in vitro by slowly reducing gastric $\mathrm{pH}$ to either 2.5 or 4.0 or when using a fast reduction to $\mathrm{pH}$ 4.0. Many milk proteins, bLF in particular, have been shown to resist degradation when milk is ingested by neonates (Chatterton et al., 2004). At pH 4, the conformation of the bLF is different and pepsin is not fully active (Roberts, 2006; Sreedhara et al., 2010), which could reduce or delay protein digestion. Future in vitro gastric digestion models should consider the buffering effect and the intended age group (infants vs. adults) when simulating human digestion.

The 2 in vivo digestion experiments performed with bLF illustrate some important intra-subject variations that may occur during the digestion process. After the first $10 \mathrm{~min}$, the protein profile and peptide identification in the gastric sample were similar for both volunteers. In contrast, all the duodenal samples aspirated from volunteer 1 were yellow, whereas the duodenal samples aspirated from volunteer 2 were clear for the samples collected during the first $20 \mathrm{~min}$. The absence of yellow color in the duodenal aspirates collected from volunteer 2 indicates that no bilirubin-containing bile was present in the duodenal juice. The low $\mathrm{pH}$ in these samples $(\mathrm{pH}<4)$ further indicates a leakage of gastric juice into the duodenum. From volunteer 2, no gastric sample was obtained after $30 \mathrm{~min}$, possibly due to the described leakage of gastric juice, thereby limiting the supply of juice through the gastric aspiration tube. In contrast, all duodenal samples from volunteer 1 seemed to contain pancreatic juice and bile, as all duodenal samples were yellow, had elevated $\mathrm{pH}(\mathrm{pH}$ 6.5-7.5), and displayed a similar protein profile as pure duodenal juice, as well as several novel gel bands that were identified to contain fragments of bLF. Results obtained on collected aspirates from humans also showed large 
individual variation in gastric and duodenal secretions. In 10 of 18 volunteers, substantial volumes of gastric juice seemed to leak and mix with duodenal juice (Ulleberg et al., 2011).

The present study showed that bLF was highly resistant at elevated gastric $\mathrm{pH}$ and that duodenal digestion as a result seems delayed. This seems to correlate well with previous reports on in vitro digestion (Eriksen et al., 2010). However, large differences in peptide sequences were observed due to various experimental conditions and enzymes sources, and very few of the peptides detected in this study matched with peptides previously reported by others (Dionysius and Milne, 1997; Hoek et al., 1997; Recio and Visser, 1999, 2000; Kimura et al., 2000; van der Kraan et al., 2004; Elbarbary et al., 2010). Recio and Visser (1999, 2000) isolated and characterized many peptides from both caprine and bovine LF after proteolysis using commercial enzymes from pig or calf, including LFampin caprine $\mathrm{f}(271-284)$ and bovine $\mathrm{f}(268-284)$, in addition to LFcin (Recio and Visser, 1999, 2000). These peptides showed strong antibacterial properties, attributed to their cationic nature (van der Kraan et al., 2004). In the present study, one peptide corresponding to a fragment of the bovine LFampin region, namely $\mathrm{f}(271-288)$, was identified after in vitro gastric digestion at $\mathrm{pH} 2.5$ (slow reduction in $\mathrm{pH})$. In addition, 2 peptides, $\mathrm{f}(271-285)$ and $f(271-287)$, were identified in the same region in duodenal aspirates collected 10 min after instillation of bLF. However, further degradation of 1 or 2 amino acids from these peptides was not detected in our study.

Another antibacterial peptide, bLF f(69-77), was identified by Elbarbary et al. (2010). This peptide was not identified in our study; however, the sequence was recognized as a part of a longer fragment, $\mathrm{f}(66-78)$, identified during both in vitro and in vivo digestion.

The bLF sequence contains some cysteine-rich areas, such as $\mathrm{f}(113-121), \mathrm{f}(230-236)$, and $\mathrm{f}(243-246)$, although no peptides were detected in these regions in our study. The reason for this might be the presence of disulfide bridges: peptides from sequences with cysteines are difficult to detect using the Mascot program and detection has to be done manually, as we did with bLFcin $\mathrm{f}(17-41)$. No peptide matching bLFcin was detected after in vitro or in vivo digestion of bLF. Because smaller peptides were observed from bLfcin $\mathrm{f}(17-41)$ after digestion of this peptide, we suggest that this peptide is further hydrolyzed. However, this may not be the case for LFcin $\mathrm{f}(26-36)$, as no shorter peptide fragments occurred after digestion of bLFcin $\mathrm{f}(26-36)$. This result is in accordance with an earlier in vivo study by Chabance et al. (1998), who did not observe any LFcin after ingestion of milk. However, this seems to contradict with other studies performed in humans, mice, and rats (Kuwata et al., 1998a,b, 2001).

Most peptide cutting points were located on the surface of the protein molecule. The few sites that were not on the surface were localized such that the residue on the other side of the detected peptide was on the surface of the protein. The proteolytic action at one site might well expose the other site to the protease. In addition, some potential cutting sites that were not processed were also detected on the surface. Multiple sequence alignment showed that peptides generated after gastric digestion at $\mathrm{pH} 2.5$, as well as after in vivo digestion, displayed a putative motif for preferred nonattacked peptide bonds, where proline is located with neighboring hydrophobic residues. This is in accordance with the analysis of peptides generated from $\beta$-lactoglobulin, $\beta$-casein, and $\kappa$-casein glycomacropeptide at pH 2.5 using HGJ (Almaas et al., 2011). Proline restricts proteolytic processing as suggested, especially toward trypsin-type specificity proteases (Jörnvall and Persson, 1983), and short proline-rich sequences with hydrophobic residues such as leucine and phenylalanine are frequent in some antimicrobial peptides (Shinnar et al., 2003). This has been termed the "proline concept" (Markert et al., 2003) and seems to be more pronounced in vitro at $\mathrm{pH} 2.5$ and in vivo. This could indicate a difference in enzyme mechanism or preference. The occurrence of leucine in addition to glycine and alanine in all 3 alignments should be noted. It should also be noted that both glycine and proline residues are helix breakers.

The possible motif(s) in the detected peptides did not, however, explain why some peptides were cut from the surface and others not. This may be linked to the saturation-unsaturation of the substrate:enzyme ratio, because different LF concentrations greatly affected protein digestion. The length of exposure to the proteases could be another factor. The protease composition used here might have preferences for some motifs over others. Bovine LF has 3 glycosylated sites in the Cterminal part of the protein, which might restrict the proteolytic processing of this part of the protein.

\section{CONCLUSIONS}

This study showed that bLF degradation and peptide formation after gastric and duodenal digestion under simulated human gastrointestinal conditions were highly dependent on gastric $\mathrm{pH}$ and the activity of human gastrointestinal juices. Many new peptides were identified, some of which were found in vitro and in vivo, and their bioactivities need to be further studied. Because of the recent approval of milk-derived LF as an 
ingredient in food products, dietary supplements with bLF should consider these novel peptides when health benefits are proposed.

\section{ACKNOWLEDGMENTS}

The present study was supported by the Norwegian University of Life Sciences (Ås, Norway), the Norwegian Research Council (Oslo), and Oestfold Hospital Trust (Fredrikstad, Norway). Technical assistance for mass spectrometry (MS) analyses was offered by Toril A. Grønset and Jack-Ansgar Bruun of The Tromsoe University Proteomic Platform (TUPP, Tromsoe, Norway) and by Irene Comi [Norwegian University of Life Sciences (UMB), Ås, Norway] for performing all aspirations of gastric and duodenal juice, conducting the enzyme assays, and being responsible for the in vivo trials.

\section{REFERENCES}

Almaas, H., E. Eriksen, C. Sekse, I. Comi, R. Flengsrud, H. Holm, E. Jensen, M. Jacobsen, T. Langsrud, and G. E. Vegarud. 2011. Antibacterial peptides derived from caprine whey proteins, by digestion with human gastrointestinal juice. Br. J. Nutr. 106:896-905.

Almaas, H., H. Holm, T. Langsrud, R. Flengsrud, and G. E. Vegarud. 2006. In vitro studies of the digestion of caprine whey proteins by human gastric and duodenal juice and the effects on selected microorganisms. Br. J. Nutr. 96:562-569.

Baldi, A., P. Ioannis, P. Chiara, F. Eleonora, C. Roubini, and D. Vittorio. 2005. Biological effects of milk proteins and their peptides with emphasis on those related to the gastrointestinal ecosystem. J. Dairy Res. 72(Spec. No.):66-72.

Bellamy, W., M. Takase, H. Wakabayashi, K. Kawase, and M. Tomita. 1992. Antibacterial spectrum of lactoferricin-B, a potent bactericidal peptide derived from the N-terminal region of bovine lactoferrin. J. Appl. Bacteriol. 73:472-479.

Brines, R. D., and J. H. Brock. 1983. The effect of trypsin and chymotrypsin on the in vitro antimicrobial and iron-binding properties of lactoferrin in human milk and bovine colostrum. Unusual resistance of human apolactoferrin to proteolytic digestion. Biochim. Biophys. Acta 759:229-235.

Chabance, B., P. Marteau, J. C. Rambaud, D. Migliore-Samour, M. Boynard, P. Perrotin, R. Guillet, P. Jolles, and A. M. Fiat. 1998. Casein peptide release and passage to the blood in humans during digestion of milk or yogurt. Biochimie 80:155-165.

Chatterton, D. E. W., J. T. Rasmussen, C. W. Heegaard, E. S. Sorensen, and T. E. Petersen. 2004. In vitro digestion of novel milk protein ingredients for use in infant formulas: Research on biological functions. Trends Food Sci. Technol. 15:373-383.

Church, F. C., H. E. Swaisgood, D. H. Porter, and G. L. Catignani. 1983. Spectrophotometric assay using ortho-phthaldialdehyde for determination of proteolysis in milk and isolated milk proteins. J. Dairy Sci. 66:1219-1227.

Dionysius, D. A., and J. M. Milne. 1997. Antibacterial peptides of bovine lactoferrin: Purification and characterization. J. Dairy Sci. 80:667-674.

Dressman, J. B., R. R. Berardi, L. C. Dermentzoglou, T. L. Russell, S. P. Schmaltz, J. L. Barnett, and K. M. Jarvenpaa. 1990. Upper gastrointestinal (GI) $\mathrm{pH}$ in young, healthy men and women. Pharm. Res. 7:756-761.

Dunn, B. M. 2002. Structure and mechanism of the pepsin-like family of aspartic peptidases. Chem. Rev. 102:4431-4458.
EFSA Panel on Dietetic Products Nutrition and Allergies. 2012. Scientific opinion on bovine lactoferrin. EFSA J. 10:1-26.

Ekmekcioglu, C. 2002. A physiological approach for preparing and conducting intestinal bioavailability studies using experimental systems. Food Chem. 76:225-230.

Elbarbary, H. A., A. M. Abdou, E. Y. Park, Y. Nakamura, H. A. Mohamed, and K. Sato. 2010. Novel antibacterial lactoferrin peptides generated by rennet digestion and autofocusing technique. Int Dairy J. 20:646-651.

Eriksen, E. K., H. Holm, E. Jensen, R. Aaboe, T. G. Devold, M. Jacobsen, and G. E. Vegarud. 2010. Different digestion of caprine whey proteins by human and porcine gastrointestinal enzymes. Br. J. Nutr. 104:374-381.

Fallingborg, J., L. A. Christensen, M. Ingeman-Nielsen, B. A. Jacobsen, K. Abildgaard, H. H. Rasmussen, and S. N. Rasmussen. 1990a. Gastrointestinal $\mathrm{pH}$ and transit times in healthy subjects with ileostomy. Aliment. Pharmacol. Ther. 4:247-253.

Fallingborg, J., L. A. Christensen, M. Ingeman-Nielsen, B. A. Jacobsen, K. Abildgaard, H. H. Rasmussen, and S. N. Rasmussen. 1990b. Measurement of gastrointestinal $\mathrm{pH}$ and regional transit times in normal children. J. Pediatr. Gastroenterol. Nutr. 11:211-214.

Freiburghaus, C., B. Janicke, H. Lindmark-Mansson, S. M. Oredsson, and M. A. Paulsson. 2009. Lactoferricin treatment decreases the rate of cell proliferation of a human colon cancer cell line. J. Dairy Sci. 92:2477-2484

Gonzalez-Chavez, S. A., S. Arevalo-Gallegos, and Q. Rascon-Cruz. 2009. Lactoferrin: Structure, function and applications. Int. J. Antimicrob. Agents 33:301.e1-301.e8.

Hamosh, M. 1998. Protective function of proteins and lipids in human milk. Biol. Neonate 74:163-176.

Hoek, K. S., J. M. Milne, P. A. Grieve, D. A. Dionysius, and R. Smith. 1997. Antibacterial activity of bovine lactoferrin-derived peptides. Antimicrob. Agents Chemother. 41:54-59.

Jörnvall, H., and B. Persson. 1983. Amino acid sequence restriction in relation to proteolysis. Biosci. Rep. 3:225-232.

Kalantzi, L., K. Goumas, V. Kalioras, B. Abrahamsson, J. B. Dressman, and C. Reppas. 2006. Characterization of the human upper gastrointestinal contents under conditions simulating bioavailability/bioequivalence studies. Pharm. Res. 23:165-176.

Kaye, J. L. 2011. Review of paediatric gastrointestinal physiology data relevant to oral drug delivery. Int. J. Clin. Pharm. 33:20-24.

Keller, J., and P. Layer. 2005. Human pancreatic exocrine response to nutrients in health and disease. Gut 54:1-28. http://dx.doi. org/10.1136/gut.2005.065946.

Kimura, M., M. S. Nam, Y. Ohkouchi, H. Kumura, K. Shimazaki, and D. Y. Yu. 2000. Antimicrobial peptide of Korean native goat lactoferrin and identification of the part essential for this activity. Biochem. Biophys. Res. Commun. 268:333-336.

Kuwata, H., K. Yamauchi, S. Teraguchi, Y. Ushida, Y. Shimokawa, T. Toida, and H. Hayasawa. 2001. Functional fragments of ingested lactoferrin are resistant to proteolytic degradation in the gastrointestinal tract of adult rats. J. Nutr. 131:2121-2127.

Kuwata, H., T. T. Yip, M. Tomita, and T. W. Hutchens. 1998a. Direct evidence of the generation in human stomach of an antimicrobial peptide domain (lactoferricin) from ingested lactoferrin. Biochim. Biophys. Acta 1429:129-141.

Kuwata, H., T. T. Yip, K. Yamauchi, S. Teraguchi, H. Hayasawa M. Tomita, and T. W. Hutchens. 1998b. The survival of ingested lactoferrin in the gastrointestinal tract of adult mice. Biochem. J. $334: 321-323$.

Laemmli, U. K. 1970. Cleavage of structural proteins during assembly of head of bacteriophage-T4. Nature 227:680-685.

Levay, P. F., and M. Viljoen. 1995. Lactoferrin-A general review. Haematologica 80:252-267.

Liepke, C., K. Adermann, M. Raida, H. J. Magert, W. G. Forssmann, and H. D. Zucht. 2002. Human milk provides peptides highly stimulating the growth of bifidobacteria. Eur. J. Biochem. 269:712718.

Macierzanka, A., A. I. Sancho, E. N. C. Mills, N. M. Rigby, and A. R. Mackie. 2009. Emulsification alters simulated gastrointestinal proteolysis of $\beta$-casein and $\beta$-lactoglobulin. Soft Matter 5:538-550. 
Markert, Y., J. Koditz, R. Ulbrich-Hofmann, and U. Arnold. 2003. Proline versus charge concept for protein stabilization against proteolytic attack. Protein Eng. 16:1041-1046.

Mulder, A. M., P. A. Connellan, C. J. Oliver, C. A. Morris, and L. M. Stevenson. 2008. Bovine lactoferrin supplementation supports immune and antioxidant status in healthy human males. Nutr. Res. 28:583-589.

Orsi, N. 2004. The antimicrobial activity of lactoferrin: Current status and perspectives. Biometals 17:189-196.

Recio, I., and S. Visser. 1999. Two ion-exchange chromatographic methods for the isolation of antibacterial peptides from lactoferrin. In situ enzymatic hydrolysis on an ion-exchange membrane. J. Chromatogr. A 831:191-201.

Recio, I., and S. Visser. 2000. Antibacterial and binding characteristics of bovine, ovine and caprine lactoferrins: A comparative study Int. Dairy J. 10:597-605.

Roberts, N. B. 2006. Review article: Human pepsins-Their multiplicity, function and role in reflux disease. Aliment. Pharmacol. Ther. $24: 2-9$.

Sánchez, L., M. Calvo, and J. H. Brock. 1992. Biological role of lactoferrin. Arch. Dis. Child. 67:657-661.

Scheele, G., D. Bartelt, and W. Bieger. 1981. Characterization of human exocrine pancreatic proteins by two-dimensional isoelectric focusing/sodium dodecyl sulfate gel electrophoresis. Gastroenterology 80:461-473.

Shevchenko, A., M. Wilm, O. Vorm, O. N. Jensen, A. V. Podtelejnikov, G. Neubauer, A. Shevchenko, P. Mortensen, and M. Mann. 1996. A strategy for identifying gel-separated proteins in sequence databases by MS alone. Biochem. Soc. Trans. 24:893-896.
Shinnar, A. E., K. L. Butler, and H. J. Park. 2003. Cathelicidin family of antimicrobial peptides: Proteolytic processing and protease resistance. Bioorg. Chem. 31:425-436.

Sreedhara, A., R. Flengsrud, T. Langsrud, P. Kaul, V. Prakash, and G. E. Vegarud. 2010. Structural characteristic, $\mathrm{pH}$ and thermal stabilities of apo and holo forms of caprine and bovine lactoferrins. Biometals 23:1159-1170.

Tomita, M., W. Bellamy, M. Takase, K. Yamauchi, H. Wakabayashi, and K. Kawase. 1991. Potent antibacterial peptides generated by pepsin digestion of bovine lactoferrin. J. Dairy Sci. 74:4137-4142.

Troost, F. J., W. H. M. Saris, and R. J. M. Brummer. 2002. Orally ingested human lactoferrin is digested and secreted in the upper gastrointestinal tract in vivo in women with ileostomies. J. Nutr. 132:2597-2600

Troost, F. J., J. Steijns, W. H. Saris, and R. J. Brummer. 2001. Gastric digestion of bovine lactoferrin in vivo in adults. J. Nutr. 131:2101-2104.

Ulleberg, E. K., I. Comi, H. Holm, E. Herud, M. Jacobsen, and G. Vegarud. 2011. Human gastrointestinal juices intended for use in in vitro digestion models. Food Dig. 2:52-61.

van der Kraan, M. I. A., J. Groenink, K. Nazmi, E. C. I. Veerman, J. G. M. Bolscher, and A. V. N. Amerongen. 2004. Lactoferrampin: A novel antimicrobial peptide in the N1-domain of bovine lactoferrin. Peptides 25:177-183.

Waterhouse, A. M., J. B. Procter, D. M. Martin, M. Clamp, and G. J. Barton. 2009. Jalview Version 2-A multiple sequence alignment editor and analysis workbench. Bioinformatics 25:1189-1191. 